Société d'histoire de la révolution de 1848 et des

révolutions du XIXe siècle

$10 \mid 1994$

Le silence au XIXe siècle

\title{
Dans les campagnes : silence quotidien et silence coutumier
}

\section{Yvonne Crebouw}

\section{OpenEdition \\ Journals}

Electronic version

URL: http://journals.openedition.org/rh19/75

DOI: $10.4000 /$ rh 19.75

ISSN: $1777-5329$

\section{Publisher}

La Société de 1848

\section{Printed version}

Date of publication: 1 June 1994

ISSN: 1265-1354

\section{Electronic reference}

Yvonne Crebouw, "Dans les campagnes : silence quotidien et silence coutumier », Revue d'histoire du XIXe siècle [Online], 10 | 1994, Online since 09 September 2008, connection on 19 April 2019. URL http://journals.openedition.org/rh19/75; DOI : 10.4000/rh19.75

This text was automatically generated on 19 April 2019

Tous droits réservés 


\title{
Dans les campagnes : silence quotidien et silence coutumier
}

\author{
Yvonne Crebouw
}

\begin{abstract}
S
In the countryside: quotidian silence and customary silence. In the countryside, eventhough here and there one can the odd quarred between farmers and workers, the silence of the fields seems to prevail. Nevertheless, if we were to look a little closer xa could see that in France the countryside is neither motionless nor speechless. From 1866, the landlords regret the time when submissive agricultural workers stayed in their places. Along with this supposed silence exists a customary silence, that of the husted-up communities. Thes communities were formed by means "other than marriage and without writtn word, between certain people, by common household and life for a year or a day...". The silence which presided their constitution then their break up explains the lack of information concerning them. In another perspective, the renewal of rents illustrates the importance of silence in local customs. Once a landlord and a worker had concluded a deal for work, three implications would appear: an obligatory notice, an implied right of renewal and an impied right of leave. The unspoken plays a major part in social relations. But this silence often hides a background of resentment.

Dans les campagnes, même si ici où là on entend le bruit des " fâcheries " entre ouvriers agricoles et employeurs, le silence des champs semble régner. Et pourtant à y regarder de plus près, les campagnes française ne sont pas immobiles et "sans voix ". Dès 1866, les grands propriétaires regrettent le temps où les ouvriers dociles se tenaient à leur place. À côté d'un silence supposé se manifeste un silence qui " a force de loi ", celui des communautés taisibles. Ces dernières se formaient "autrement que par le mariage et sans écrit, entre certaines personnes, par une
\end{abstract}


habitation et une vie commune pendant un an et un jour... ". L'intention marquée de vivre en communauté était essentielle. Le silence qui préside à leur constitution puis à leur désagrégation explique le peu d'informations les concernant. Dans un autre registre le renouvellement des louées illustre le poids du silence dans les usages. Lorsqu'un maître et un ouvrier agricole avait conclu un accord au sujet du travail de ce dernier, trois cas de figure se présentaient: le nécessaire avertissement; la tacite reconduction et le congé tacite. Le non-dit joue donc un rôle majeur dans les relations sociales. Reste que le silence dissimule bien souvent un arrière monde de rancoeurs.

INDEX

Mots-clés: Silence, Histoire rurale 